\title{
A Comparative Study of Conventional Cytology and Cellblock Method in Diagnosis of Pleural Effusion and their Correlation with Clinicopathological and Radiological Diagnosis
}

\author{
MAHA A. MOHAMMED, M.D.*; ZEINAB H. EL-BADAWI, M.D.*; HALA S.E. ALAA EDIN, M.D.**; \\ KHALED M. ABD EL-AAL, M.D.*** and EMAN M.S. MUHAMMAD, M.D.* \\ The Department of Pathology, Faculty of Medicine, Sohag* and South Valley** Universities and \\ The Department of Cardiothoracic Surgery, Faculty of Medicine, Sohag University***, Egypt
}

\begin{abstract}
Background: Cytological Smear (CS) is extremely useful in patients with pleural effusions especially when malignancy is suspected. Cellblock (CB) technique is another method for examination of pleural fluid. In this study we aimed to compare the diagnostic yields of CS and CB technique and the combination of both, regardless of the etiology of Pleural Effusion (PE), and to compare their results with clinicopathological and radiological results.
\end{abstract}

Aim of Study: This study aims to compare the diagnostic yields of CS and CB techniques and their combination in diagnosis of PF regardless of its etiology.

Material and Methods: 140 cases of PE samples were obtained, CS and CB were done, results were compared with each other and correlated with the clinicopathological and radiology results when available.

Results: Agreement between results of $\mathrm{CS}$ and $\mathrm{CB}$ was $87.86 \%(p=0.0001)$. There was an agreement between CS at one side and either radiological findings or biopsy at the other side; $88.89 \%$ and $88.1 \%$ respectively ( $p=0.0001$ for each). There was an agreement also between CB results and either radiological findings or biopsy; $94.87 \%$ and $95.24 \%$ respectively ( $p=0.0001$ for each).

Conclusions: Our study showed that the CB method yielded better results in diagnosis of malignancy in PE. Therefore, this technique could be considered as a useful adjuvant in evaluating PE fluid cytology and final cytodiagnosis, along with the routine CS method.

Key Words: Cytological Smear $(C S)-$ Cellblock $(C B)-$ Cytology - Pleural Effusion (PE).

\footnotetext{
Correspondence to: Dr. Eman M.S. Muhammad

E-Mail: eman shalabi@med.sohag.edu.eg. eman_shalabi@hotmail.com, e salah@yahoo.com emanmuhammad7@gmail.com
}

\section{Introduction}

PLEURAL effusion is an abnormal accumulation of fluid in the pleural cavity [1]. It may suggest pulmonary, pleural, or extrapulmonary disease [2]

Thoracentesis is a diagnostic procedure for patients with PF. Pleural fluid obtained by this procedure should be submitted for biochemical, microbiological, and cytological study [3]

CS is extremely useful in evaluating PF as it provides a diagnostic rate of $60 \%$ [4]. It will not only help in diagnosis of PF, but also in defining stage of malignancy and evaluating disease prognosis [1]. However, conventional CS can be a diagnostic problem, as differentiation between benign and malignant cellular changes may be elusive, given its lower diagnostic yield [5]

$\mathrm{CB}$ technique is one of the oldest methods for evaluation of architecture and obtaining multiple sections for special stains and immunohistochemistry [6]. Because of its safe and easy collection, $\mathrm{CB}$ of $\mathrm{PF}$ is a useful diagnostic alternative for pleural biopsy for diagnosing malignancy [7]

\section{Material and Methods}

This study included 140 cases of PE samples, obtained from Department Cardiothoracic Surgery, Sohag University Hospital, during the period from January 2016 to June 2017 . They included all age groups and both sexes. All PE samples were of exudative type and of their amount was more than $30 \mathrm{ml}$ for each sample.

Written consent was taken from each patient and the study was approved by the Institutional 
Ethics Research Committee before starting the work. Clinical, laboratory, radiological and thoracoscopic findings were reported for studied cases if available.

The findings of CS and CB examination were discussed separately all through the study and they correlated with each other and with the clinicoradiological diagnosis at the end of the study.

Any clots were removed and the fluid was poured into tubes to be centrifuged until the cells are deposited. Fifteen $\mathrm{ml}$ was used for the CS and fifteen $\mathrm{ml}$ was used for $\mathrm{CB}$ preparation. Centrifugation speed and time are not critical; 5min at 1500 r.p.m. is generally sufficient $[\mathbf{8 , 9 ]}$

\section{Preparation of CS:}

The supernatant was removed. One or two drops from cell sediment were transferred to the slide and spread using the end of another slide as a spreader, making a smear exactly as for a blood film. CS was fixed in $95 \%$ ethyl alcohol for a minimum of 15 minutes and stained with $\mathrm{H} \& \mathrm{E}$ and Papanicolaou stain.

CB (Nathan Alcohol Formalin Substitute; NAFS method):

The sediment of the second tube was used for $\mathrm{CB}$ preparation. Fixation was done using $2 \mathrm{ml}$ of $10 \%$ buffered formalin (nine parts absolute ethyl alcohol + one part $40 \%$ formalin), then recentrifuged. The sediment pellet was removed after decanting supernatant and was processed like tissue for obtaining paraffin block. Sections from the CB were stained by $\mathrm{H} \& \mathrm{E}$ stain $[\mathbf{1 0 , 1 1 ]}$.

\section{Interpretation of $C S$ and $C B$ :}

Samples were studied in detail taking into account the available clinical data, various investigation reports and morphological details. CS samples were categorized as benign, suspicious for malignancy, or malignant lesions. Various morphological criteria that were taken into account included the cellularity, arrangement of the cells (acini, papillae and cell balls) and the cytoplasmic and nuclear details. All these criteria were put together and used for classifying the various cytomorphological patterns.

Comparative evaluation of CS versus $\mathrm{CB}$ technique was conducted. The cytomorphological characters were studied to identify malignancy and the most probable primary site. We used histopathology of the obtained tissue biopsy as our gold standard as a referencing for final diagnosis to which CS interpretation and $\mathrm{CB}$ evaluation were compared, as referred to by Bhanvadia, [12] .

\section{Statistical analysis:}

Data were analyzed using STATA intercooled version 12.1. Quantitative data were represented as mean \pm Standard Deviation (SD), median and range. Qualitative data was presented as number and percentage. Agreement between the test results was obtained by Kappa test. Graphs were made using Excel, $p$-value less than 0.05 was considered significant. Sensitivity, specificity, positive, and negative predictive values derived from the receiver operating characteristic curve were calculated.

- Sensitivity $=$ True positive/true positive + false negative.

- Specificity $=$ True negative/true negative + false positive.

- Positive predictive value $=$ True positive/true positive + false positive.

- Negative predictive value $=$ True negative/true negative + false negative.

\section{Results}

This study included 140 cases of PE; 78 males and 62 females. Their ages range between 14 and 90 with a median of 55 (mean \pm SD of $53.03 \pm$ 16.36). Patients presented with cough, dyspnea, pleuritic chest pain in 97,42 , and 54 cases respectively (Table 1).

Table (1): Clinicopathological and radiological findings.

\begin{tabular}{ll}
\hline Variables & Summary statistics \\
\hline $\begin{array}{l}\text { Age: } \\
\text { Median age (years) }\end{array}$ & 55 (range14-90) \\
Gender: & \\
$\quad$ Females & $62(44.29 \%)$ \\
Males & $78(55.71 \%)$ \\
Site: & \\
Left & $64(45.71 \%)$ \\
Right & $69(49.29 \%)$ \\
Bilateral & $7(5.00 \%)$ \\
Radiology examination (117 cases): & \\
$\quad$ Negative & $96(85.05 \%)$ \\
Positive & $21(17.95 \%)$ \\
Biopsy examination (84 cases): & \\
Negative & $63(75.00 \%)$ \\
Positive & $21(25.00 \%)$ \\
\hline
\end{tabular}

\section{$C S$ and $C B$ examination and agreement between} them:

Tables $(2,3)$ and Fig. (1) summarize the results of CS and CB and agreement between them. CS examination revealed that there were 109 negative, 11 atypical, 6 suspicious for malignancy and 14 
frankly malignant cases. CB examination revealed 106 inflammatory, 11 atypical, 3 suspicious for malignancy and 20 malignant cases. Comparing the results of CS with that of $\mathrm{CB}$ examination for all the 140 studied cases revealed $87.86 \%$ agreement $(p=0.0001)$.

Table (2): Agreement between CS and CB examination.

\begin{tabular}{|c|c|c|c|c|c|}
\hline & \multicolumn{4}{|c|}{ Cellblock } & \multirow[b]{2}{*}{ Total } \\
\hline & Negative & Positive & Atypical & $\begin{array}{l}\text { Suspicious } \\
\text { for } \\
\text { malignancy }\end{array}$ & \\
\hline $\begin{array}{l}\text { Cytological } \\
\text { Smear: } \\
\text { - Negative } \\
\text { - Positive } \\
\text { - Atypical } \\
\text { - Suspicious for } \\
\text { malignancy }\end{array}$ & $\begin{array}{l}100 \\
2 \\
3 \\
1\end{array}$ & $\begin{array}{l}6 \\
12 \\
0 \\
2\end{array}$ & $\begin{array}{l}3 \\
0 \\
8 \\
0\end{array}$ & $\begin{array}{l}0 \\
0 \\
0 \\
3\end{array}$ & $\begin{array}{l}109 \\
14 \\
11 \\
6\end{array}$ \\
\hline Total & 106 & 20 & 11 & 3 & 140 \\
\hline \multicolumn{6}{|c|}{ Percent agreement $=87.86 \%$, Kappa $=0.69, p<0.0001$} \\
\hline
\end{tabular}
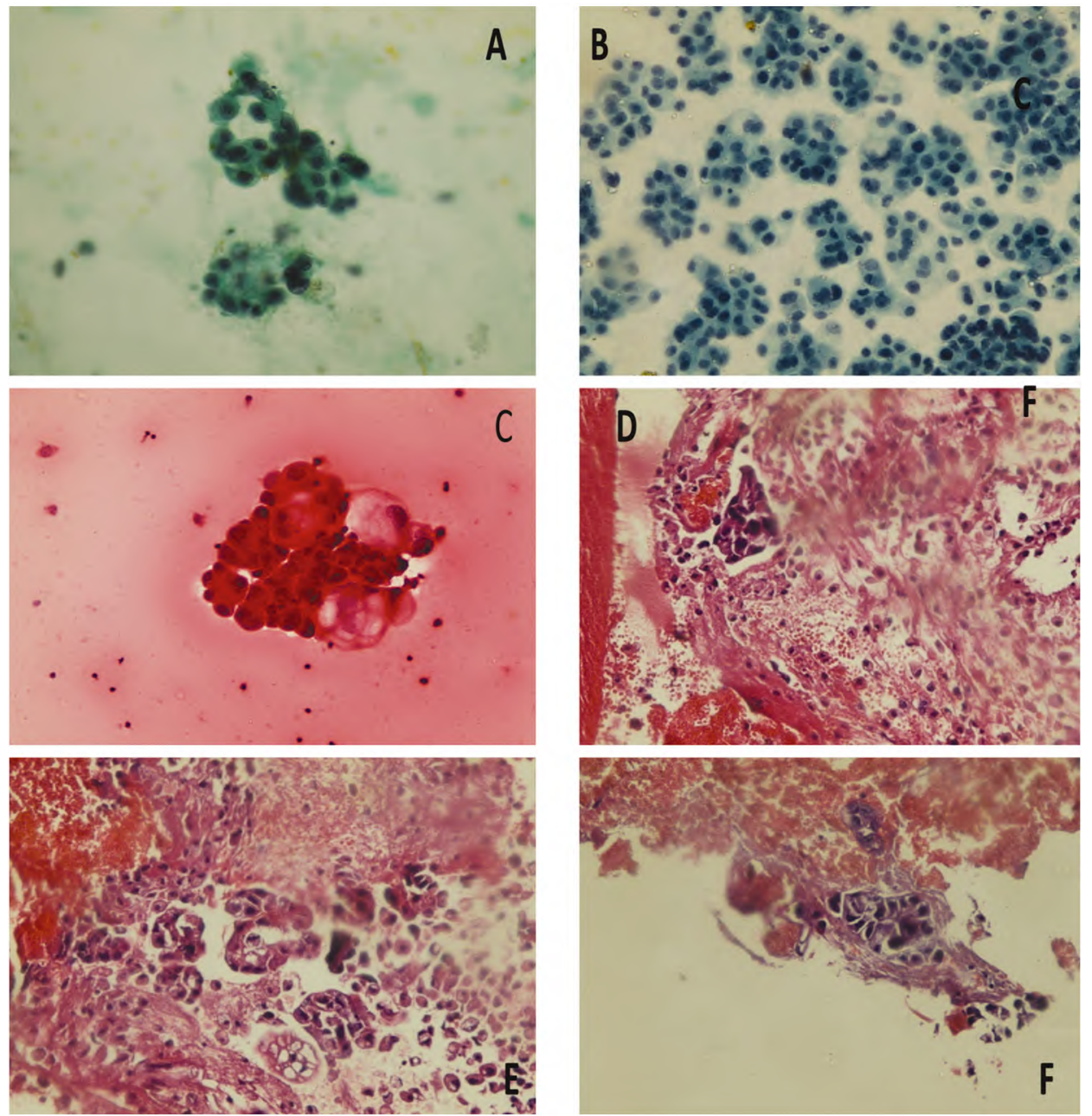

Fig. (1): CS and CB from different types of PF (A) CS showed reactive mesothelial cells, (B) CS showed malignant mesothelioma, Papanicolaou stain (C) CS showing malignant mesothelioma, $\mathrm{H}$ \& $\mathrm{E}$ X400. (D) CB showing malignant mesothelioma, H \& E (E): CB showing moderately differentiated adenocarcinoma. $\mathrm{H} \& \mathrm{E}(\mathrm{F}) \mathrm{CB}$ showing poorly differentiated adenocarcinoma. H \& E All pictures were taken at X400. Differentiated adenocarcinoma. H \& E All pictures were taken at X400.
Out of the 23 cases diagnosed as malignant by $\mathrm{CB}, 6$ cases were missed by conventional CS examination. Also out of the 20 cases diagnosed as malignant by the conventional CS examination, 3 cases were excluded by $\mathrm{CB}$ examination. All the results were confirmed by surgical biopsy.

Table (3): Comparing diagnosis by CS and CB examination.

\begin{tabular}{lccc}
\hline & \multicolumn{2}{c}{ Cellblock } & \\
\cline { 2 - 3 } & Positive & Negative & Total \\
\hline $\begin{array}{l}\text { Cytological Smear: } \\
\text { Positive } \\
\text { Negative }\end{array}$ & 17 & 3 & 20 \\
\hline Total & 6 & 114 & 120 \\
& 23 & 117 & 140 \\
& $\begin{array}{c}\text { Percent agreement }=93.57 \%, \\
\text { Kappa }=0.75, p<0.0001\end{array}$ & \\
\hline
\end{tabular}
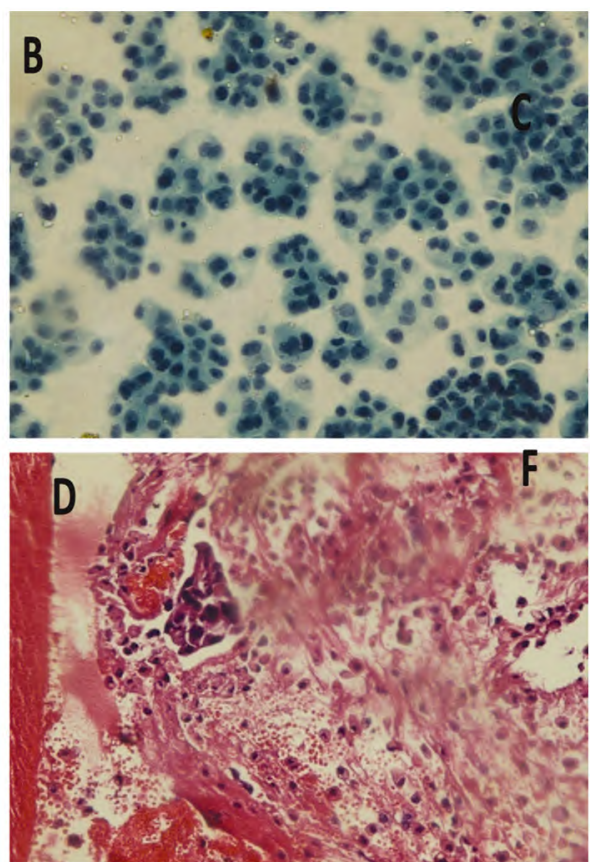
Biopsy examination and its agreement with that of $C S$ and $C B$ :

Surgical biopsies were obtained from 84 cases and revealed that $63(75 \%)$ cases were negative for malignancy and $21(25 \%)$ cases were positive for malignancy.

Results of CS and CB examination were compared with results of biopsy as gold standard for diagnosis in the 84 cases for which biopsy was done. Our study showed that results for CS examination the sensitivity $=66.67 \%$, specificity $=95.24 \%$,

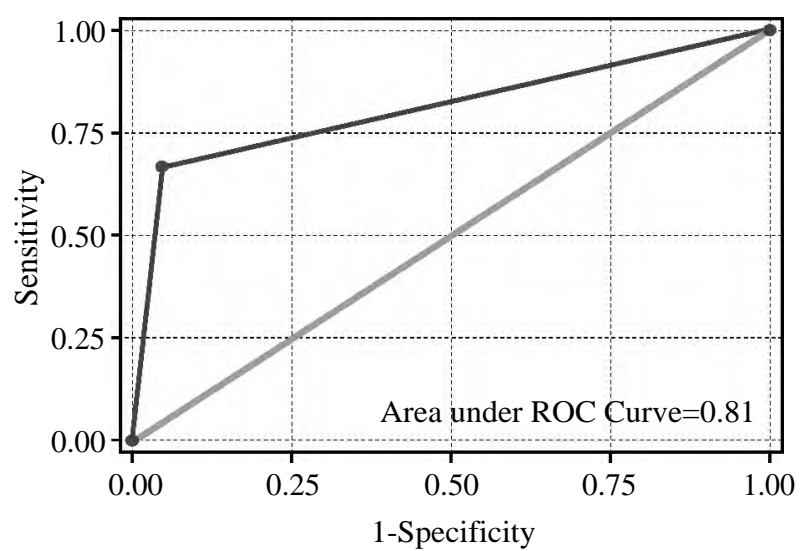

Graph (1): Roc curve of CS predicting positive biopsy.

\section{Radiological examination and its agreement} with $C S$ and $C B$ examination:

Table (4) summarize radiological examination (plain X-ray) of 117 cases which revealed that $96 / 117(82.05 \%)$ cases were negative for malignancy and $21 / 117(17.95 \%)$ cases were positive for malignancy. Results of CS examination showed positive predictive value $=82.35 \%$, negative predictive value $=89.55 \%$ and accuracy $=80.95 \%$. Percent agreement $=88.10 \%, \mathrm{Kappa}=0.66, p<0.0001$ and area under curve $(95 \%$ CI interval $)=0.81(0.74$ 0.88 ) as shown in Graph (1). While for CB examination the sensitivity $=90.48 \%$, specificity $=96.83 \%$, positive predictive value $=90.48 \%$, negative predic tive value $=96.83 \%$ and accuracy $=93.65 \%$. Percent agreement $=95.24 \%, \mathrm{Kappa}=0.87, p<0.0001$ and area under curve $(95 \%$ CI interval $)=0.94(0.87$ 0.99 ) as shown in Graph (2). All were summarized in (Table 4), Graph (3).

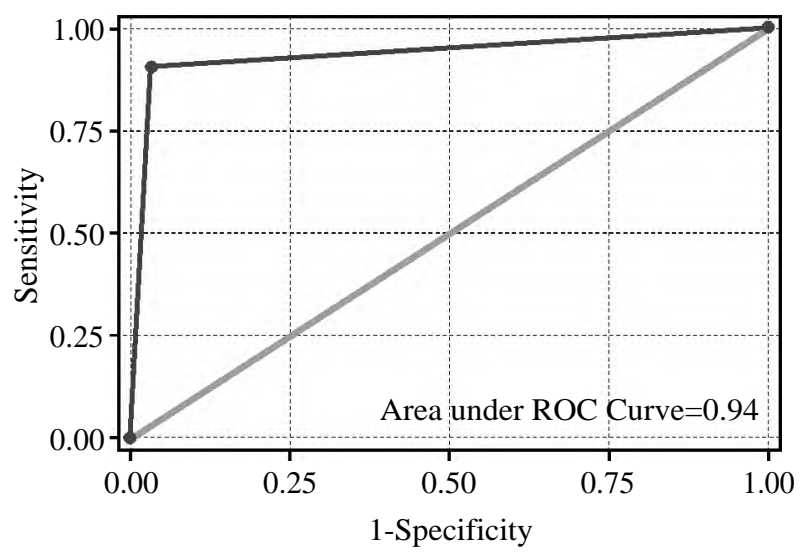

Graph (2): Roc curve of CB predicting positive biopsy.

percent agreement $=73.50 \%, \mathrm{Kappa}=0.65, p<0.0001$ compared with radiological examination.

$\mathrm{CB}$ examination were compared with that of radiological examination for the 117 cases who had radiological examination with percent agreement $=79.49 \%, \mathrm{Kappa}=0.51, p<0.0001$.

Table (4): Correlation between CS and CB examination in one side and biopsy and radiological examination at the other side.

\begin{tabular}{|c|c|c|c|c|c|c|}
\hline & \multicolumn{3}{|c|}{ Cytological Smear } & \multicolumn{3}{|c|}{ Cellblock } \\
\hline & Positive & Negative & Statistics & Positive & Negative & Statistics \\
\hline $\begin{array}{l}\text { Biopsy: } \\
\text { Positive }\end{array}$ & 14 & 7 & $\begin{array}{l}- \text { Percent agreement }=88.1 \%, \\
\mathrm{kappa}=0.66, p<0.0001\end{array}$ & 19 & 2 & $\begin{array}{c}- \text { Percent agreement }=95.24 \%, \\
\text { kappa }=0.87, p<0.0001\end{array}$ \\
\hline Negative & 3 & 60 & $\begin{array}{l}\text { - Area under curve } \\
(95 \% \text { CI interval })= \\
0.91(0.84-0.89) \\
\text { - Sensitivity }=66.67 \% \\
\text { Specificity=95.24\% } \\
\text { - } \text { Positive predictive value } \\
=82.35 \% \\
\text { - } \text { Negative predictive value } \\
=89.55 \% \\
\text { - Accuracy }=80.95 \%\end{array}$ & 2 & 61 & $\begin{array}{l}\text { - Area under curve } \\
(95 \% \text { CI interval })= \\
0.97(0.94-0.99) \\
\text { - } \text { Sensitivity }=90.48 \% \\
\text { Specificity }=96.83 \% \\
\text { - } \text { Positive predictive value } \\
=90.48 \% \\
\text { - } \text { Negative predictive value } \\
=96.83 \% \\
\text { - } \text { Accuracy }=93.65 \%\end{array}$ \\
\hline \multicolumn{7}{|l|}{ Radiology: } \\
\hline Positive & 14 & 7 & - Percent agreement $=88.89 \%$ & 19 & 2 & - Percent agreement $=94.87 \%$ \\
\hline Negative & 6 & 90 & kappa $=0.62, p<0.0001$ & 4 & 92 & kappa $=0.83, p<0.0001$ \\
\hline
\end{tabular}


Graph (3): A comparison between CS and CB examination as regard to sensitivity, specificity, positive and negative predictive values, and accuracy.

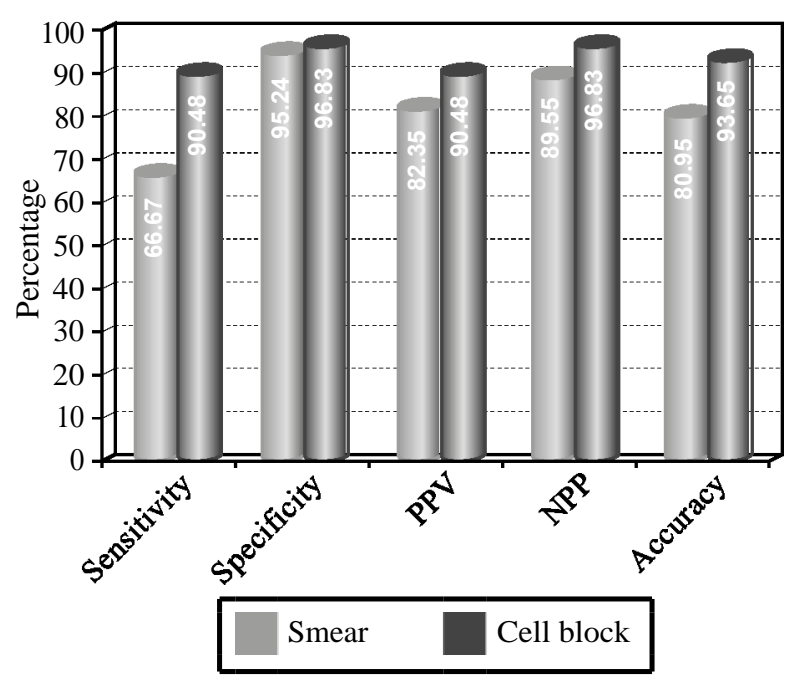

Graph (3): Comparison between CS and CB examination.

\section{Discussion}

\section{Comparison between $C S$ and $C B$ :}

Diagnosis of pleural disease can be made by direct examination of the pleura itself or by indirect evaluation of PE that accumulates in the pleural cavity. As it is a non-invasive technique and available in most hospitals, thoracentesis to retrieve PE for examination is well accepted as an initial investigation [3]

The diagnostic performance of cytological study of pleural fluid may be attributable to the fact that cell population present in the sediment is representative of larger surface area than that obtained by needle biopsy [8]

Although preparation of CS is a much simpler procedure than that of paraffin sections, it has some limitations. The sensitivity of this method for the presence of malignancy is only $40-70 \%$. This may be attributed to overcrowding of cells, cell loss and different laboratory methods of processing of $\mathrm{PF}$ [6].

Another limitation in CS usage is that in some cases it is difficult to distinguish reactive mesothelial cells from malignant cases, especially when mesothelial cells showed marked atypia or when malignant tumors are well differentiated. Other limitations were lack of tissue architecture, reactive mesothelial cells, abundance of inflammatory cells and paucity of representative cells [6].
Hasteh et al., [13] stated that the cytological features commonly used to identify malignancy, including nuclear pleomorphism, macronucleoli, large cellular aggregates, papillary-like tissue fragments, and cell-in-cell engulfment are helpful features. However, these features have limited use in PE examination, because they may also be present in florid reactive mesothelial hyperplasia. With CB technique all these features are appreciated and lesions will be put in their proper prospective.

Therefore, we conducted this study to explore the benefits of CB when integrated as a part of PE examination in routine clinical practice.

CS examination was compared with CB examination of the whole 140 patients in our study with percent agreement was $87.86 \%$ and Kappa was 0.69 which reflects fair agreement between both methods of examination. In the current study, 6/23 (4.29\%) patients diagnosed as malignant by CB were missed by conventional CS examination. In addition, $3 / 20(2.14 \%)$ patients diagnosed as malignant by conventional CS examination were excluded by CB examination. Most of the results were confirmed by surgical biopsy.

Matreja et al., [14] reported that CB examination identified 3/153 (1.9\%) additional cases as malignancy compared to those diagnosed by CS alone, and 6/153 (3.9\%) cases diagnosed as malignant by $\mathrm{CS}$ alone were excluded from malignancy by CB examination. This slight difference in their findings from these reported in our study may be due to the difference in the number of malignant cases in both studies.

There was significant difference comparing the results of CS and CB examination $(p<0.0001)$, which higher than that previously reported by Katti et al., [11]; $(p<0.001)$. This difference may be due to using pleural, peritoneal and pericardial fluid samples in their study, compared to using only PE in the current study.

In our study the sensitivity of CS examination compared to surgical biopsy examination was $66.67 \%$, close to that $68.4 \%$ found by Gaur et al., [15]. However, the sensitivity of CS examination is higher than that found by Bhanvadia et al., (2014) [11], which was $55 \%$ only. This difference may be due to larger amount of pleural fluid used in our study (15ml), in comparison to $5 \mathrm{ml}$ used by Bhanvadia et al., (2014) [11]

In our study the specificity of CS examination compared to surgical biopsy examination was $95.24 \%$, comparable to that found in other studies 
which was $96 \%$ and $97 \%$ by Bhanvadia et al., and Ugurluoglul et al., [12,16] and respectively.

Positive and negative predictive values of CS examination compared to surgical biopsy examination in our study were $82.35 \%$, and $89.55 \%$ respectively. They were higher than those reported by Ugurluoglul et al., [16] who found positive and negative predictive values of $67.5 \%$, and $78.6 \%$ respectively. This may be due to centrifuging the fluid at $1500 \mathrm{rpm}$ in our study compared to 2000rpm in their study.

The accuracy of smear examination was $80.95 \%$ which is higher than that; $71.42 \%$ found by Thapar et al., [17]. This difference may be due to using pleural, peritoneal and pericardial effusion samples in their study, while only PE aspirate was used in the current study.

Percent agreement between CS examination and biopsy examination in our study was $88.10 \%$ and Kappa $=0.66$ which reflects fair agreement between both methods of examination $(p<0.0001)$. This reflects high significance of the CS examination.

Area under curve for CS examination compared to biopsy examination in our study was 0.91 , which means highly accurate results of CS examination.

\section{Correlation between $C B$ and biopsy:}

Sensitivity of $\mathrm{CB}$ examination compared to biopsy examination in our study was $90.48 \%$, while it was $100 \%$ by Ugurluoglul et al., [16] . This difference may be due to using Nathan alcohol formalin substitute method in our study, contrasting with using $10 \%$ formalin as fixative in their study.

Specificity of CB examination compared to biopsy examination in our study was $96.83 \%$ which is much higher than that (83\%) found by Katti et al., [11], but lower than the specificity of $\mathrm{CB}$ examination; $100 \%$ reported by Ugurluoglul et al., [16]. These differences may be explained by different methods used in fixation of the specimens in each study. While we used formalin and alcohol solution in 1:9 ratio as a fixative, Katti et al., [11] used equal volumes of alcohol and formalin, whereas $10 \%$ formalin was used as fixative in the study of Ugurluoglul et al., [16].

Positive and negative predictive values of $\mathrm{CB}$ examination compared to biopsy examination in our study was $90.48 \%$ and $96.83 \%$ respectively. Predictive values of $\mathrm{CB}$ examination compared to biopsy were $100 \%$ too as reported by Ugurluoglul et al., [16]. This may be due to the different method of fixation mentioned above.
In our study the accuracy of CB technique was $93.65 \%$, higher than previously reported by Thapar et al., [17] which was $85.72 \%$. This difference may be due to the difference in the method of fixation as they used equal volumes of alcohol and formalin for fixation.

Percent agreement between CB and biopsy examination was 95.24\% and Kappa was 0.87, which reflects extremely high degree of agreement between both methods $(p<0.0001)$. This result reflects high significance of the $\mathrm{CB}$ examination method.

Area under curve for CB examination compared to biopsy examination in our study was 0.97 , which means highly accurate results of $\mathrm{CB}$ examination.

Simultaneous use of CS and CB examination in the current study, increased the diagnostic accuracy by $12.7 \%$ similar to $12 \%$ increase reported by Richardson et al., [18], and 13\% reported by Thapar et al., [17]

Simultaneous use of CS and CB examination increased the sensitivity of diagnosis to become $90.48 \%$ compared to $66.67 \%$ with CS examination alone. With CS and CB technique, additional sections could be obtained which facilitated the use of special stains or immunohistochemical studies. Matreja et al., [14] showed increase in the sensitivity of diagnosis from $69.2 \%$ by CS examination alone to become $92.3 \%$ by combined use of CS and CB techniques.

Conclusion, our study showed that the $\mathrm{CB}$ method yielded more cellularity and better architectural patterns which improved the diagnosis of malignancy. Multiple sections could be obtained if required for special stain or immunohistochemistry. Therefore, CB technique could be considered as a useful adjuvant in evaluating fluid cytology for final cytodiagnosis, along with the routine CS method [6].

\section{References}

1- BISWAS B., SHARMA S.K., NEGI R.S., GUPTA N., JASWAL V.M., NIRANJAN N.: Pleural effusion: Role of pleural fluid cytology, adenosine deaminase level, and pleural biopsy in diagnosis. J. Cytol., 33 (3): 159-62, 2016.

2- MEDFORD A. and MASKELL N.: Pleural effusion. Postgrad. Med. J., 81 (961): 702-10, 2005.

3- ASSAWASAKSAKUL T., BOONSARNGSUK V. and INCHAROEN P.: A comparative study of conventional cytology and cellblock method in the diagnosis of pleural effusion. J. Thorac. Dis., 9 (9): 3161-7, 2017. 
4- RIVERA M.P., MEHTA A.C. and WAHIDI M.M.: Establishing the diagnosis of lung cancer: Diagnosis and management of lung cancer, 3 rd ed: American College of Chest Physicians evidence-based clinical practice guidelines. Chest, 143 (5 Suppl): e142S-e165S. doi: 10.1378/ chest. 12-2353, 2013.

5- CARRETERO R.G., MANOTAS-HIDALGO M.L., BRUGERA M.R. and MOHAMED L.E.: Pleural effusion of malignant etiology: Cellblock technique to establish the diagnosis. BMJ Case Rep., doi:10.1136/bcr-2016215140, 2016.

6- SHIVAKUMARSWAMY U., ARAKERI S.U. and KARIGOWDAR M.H.: Diagnostic utility of the cellblock method versus the conventional smear study in pleural fluid cytology. J. Cytol., 29: 11-5, 2012.

7- MIYOSHI S., SASADA S., IZUMO T., MATSUMOTO Y. and TSUCHIDA T.: Diagnostic Utility of Pleural Fluid Cellblock versus Pleural Biopsy Collected by Flex-Rigid Pleuroscopy for Malignant Pleural Disease: A Single Center Retrospective Analysis. PLoS One, 11 (11): e0167186, 2016.

8- SHOBHA S.N. and KODANDASWAMY C.R.: Utility of modified cellblock technique in cases of pleural effusion suspected of malignancy. Int. J. Health Sci. Res., 3: 338, 2013.

9- SHOBHA S.N. and KODANDASWAMY C.R.: A comparative study of conventional cytology and cellblock method in the diagnosis of pleural effusion. J. Thorac. Dis., 9 (9): 3161-7, 2017.

10- NATHAN N., NARAYAN E., SMITH M. and HORN M.: Cellblock cytology, improved preparation and its efficacy in diagnostic cytology, Am. J. Clin. Pathol., 114: 599-606, 2000.
11- KATTI R., BOMMANAHALLI B. and MURTHY N.: Diagnostic role of cell block method in serous effusions, A comparative study with conventional smear cytology. Indian J. Path. Oncol., 3: 281-4, 2016.

12- BHANVADI V.M., SANTWANI P.M. and VACHHANI: Analysis of diagnostic value of cytological smear method versus cellblock method in body fluid cytology: Study of 150 cases. Ethiop. J. Health, 24 (2): 125-31, 2014.

13- HASTEH F., LIN G., WEINDER N. and MICHAEL C.: The use of immunohistochemistry to distinguish reactive mesothelial cells from malignant mesothelioma in cytologic effusions. Cancer Cytopathology, 118: 65-112, 2010.

14- MATREJA S., MALUKANI K., NANDEDKAR S., VARMA A., SAXENA A. and AJMERA A.: Comparison of Efficacy of Cell Block versus Conventional Smear Study in Exudative Fluids. N.P.M.J., 24: 196: 149-84, 2017.

15- GAUR D., CHAUHAN N., KUSUM A., HARSH M., TALEKAR M., KISHORE S. and PATHAK V.: Pleural Fluid Analysis-Role in Diagnosing Pleura Malignancy, Journal of Cytology, 24: 183-8, 2007.

16- UGURLUOGLUL C., KURTIPEK E., UNLU Y., ESME H. and DUZGUN N.: Importance of the Cell Block Technique in Diagnosing Patients with Non-Small Cell Carcinoma Accompanied by Pleural Effusion. Asian Pacific J. Cancer Preven., 16: 3057-60, 2015.

17- THAPAR M., MISHRA R., SHARMA A. and GOYAL V.: Critical analysis of cell block versus smear examination in effusions. J. Cytol., 26: 123-91, 2017.

18- RICHARDSON H., KOSS L. and SIMON T.: An evaluation of the concomitant use of cytological and histological techniques in the recognition of cancer in exfoliated material from various sources. Cancer, 8: 948-50, 1955.

\title{
دراسة مقارنة بين علم الخلايا التقليدى والكتلة الخلوية

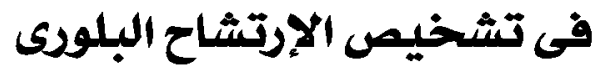

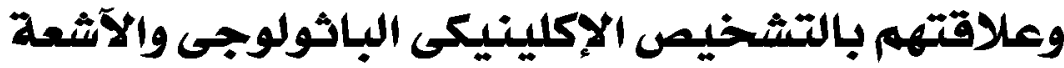

\author{
المسحة الخلوية تعد فى غاية الآهمية لمرضى الإرتثاح البلوىى خاصة إذا كان هنال إثتباه في وجه آورام خبيثة، وتعتبر الكتلة الخلوية \\ طريقة آخرى لفحص السائل البلورى. \\ وقد كان هدفنا في هذه الدراسة آن نقان بين نتيجة المسحة الخلوية والكتة الخلوية ودراسة مدى آهمية القيام بهما معاً. وكذلك دراسة

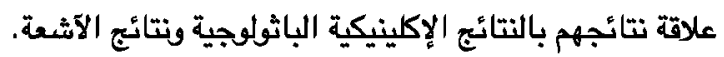 \\ الطرق والآدوات: تم آخذ . عا عينة مختلة من حالات الإرتثاح البلوىى وقمنا بعمل المسحة الخلوية وكذلك الكتلة الخلوية وتم مقارنة

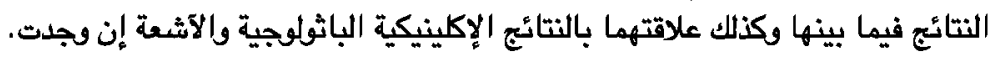 \\ النتائج: كان هناك توافق ذو دلالة إحصائية بين المسحة التقليدية والبلوك الخلويز وكان هناك توافق ذو دلالة إحصائية. وكان هناك آيضاً

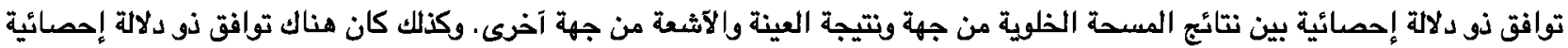

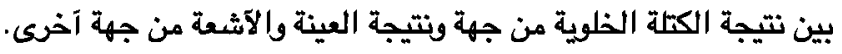 \\ الخلاصة: وجدنا من هذه الدراسة آن طريقة الكلة الخلوية تعطى نتائج آفضل في تشخيص الآقدام الخبيثة. ولذلك يجب إضافة هذه الطريقة \\ لتقييم السوائل الخلوية مع وجود المسحة التقليدية.
}

